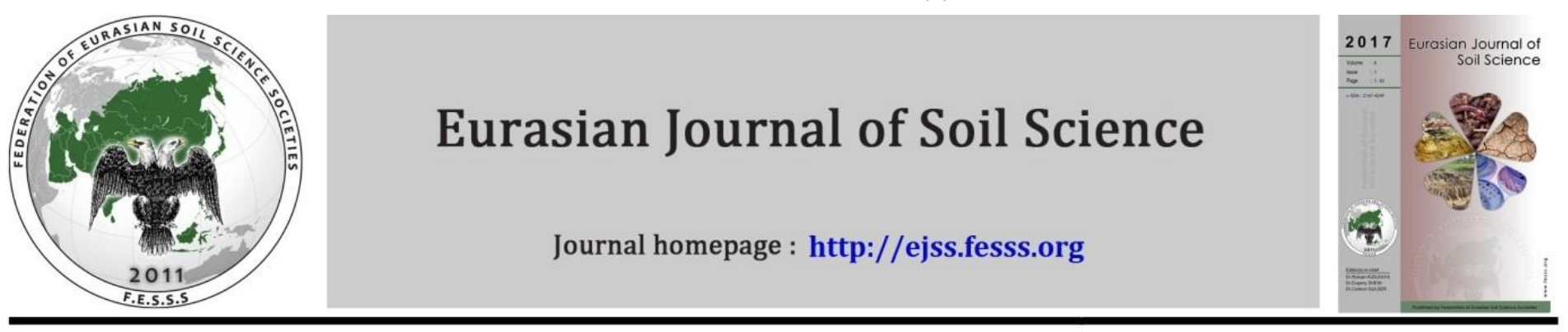

\title{
DTPA-extractable micronutrients: A geostatistical study from Ordu, Turkey
}

\author{
Tayfun Aşkın *, Ferhat Türkmen, Ceyhan Tarakçığlu, \\ Sezen Kulaç, Selahattin Aygün
}

Ordu University, Faculty of Agriculture, Department of Soil Science and Plant Nutrition, Ordu, Turkey

\section{Article Info}

Received : 16.07.2016

Accepted : 11.11 .2016

\begin{abstract}
In present study, geostatistical techniques were applied to assess the spatial variability of DTPA-extractable micronutrients which are named heavy metals as chemistry such as; iron $(\mathrm{Fe})$, copper $(\mathrm{Cu})$, manganese $(\mathrm{Mn})$ and zinc $(\mathrm{Zn})$ in the non-tillaged layer in Ordu province- Altınordu district, Black sea region, Eastern part of Turkey. Study area was approximately 40095.8 ha where was divided into grids with $2500 \times 2500 \mathrm{~m}$ spacing with including 66 sampling points from $0-0.2 \mathrm{~m}$ in depth. Soil reaction $(\mathrm{pH})$ was the least variable property while electrical conductivity (EC) was the most variable. While the highest nugget effect occurred for Ext-Cu with moderate spatial dependence, the lowest for Ext-Mn with strong spatial dependence. The greatest range of influence (17424 m) occurred for Ext-Cu and the least range (692 m) for Ext-Zn.
\end{abstract}

Keywords: DPTA-extractable micronutrients, spatial variability, site specific management.

(C) 2017 Federation of Eurasian Soil Science Societies. All rights reserved

\section{Introduction}

The micronutrients $\mathrm{B}, \mathrm{Cl}, \mathrm{Cu}, \mathrm{Fe}, \mathrm{Mn}, \mathrm{Mo}$, and $\mathrm{Zn}$ are the seven essential elements for plants at requirement levels of less than $0.10 \%$ in the plant's dry matter. They are essential for healthy growing of plants which are only needed in very small quantities. Micronutrients are nutrients required by humans and other organisms throughout lifetime even in small quantities, to manage a range of physiological functions. Plants require very small amounts of micronutrients for optimal growth and excessive amount of micronutrients concentrations in soil can be harm for plants. Soil micronutrient deficiency is considerably important for yield, food quality and nutrient balance in human and animal nourishments. Also, they have huge important for environmental conservation On the other hand, for the better management in agricultural production areas, determination of soil micronutrient content has a vital importance (Epstein, 1972; Singh et al., 1985; Glass, 1989; Römheld and Marschner, 1991; Singh, 2008; Akbaș et al., 2009; Thakur et al., 2011; Sharma and Jassal, 2013).

Soil properties in all ecosystems are controlled by a variety of factors that operate at different spatial and temporal scales. Soil physical, chemical and biological properties are all likely to change markedly across small distances, within a few hectares of agricultural fields (Cambardella et al., 1994; Chien et al., 1997; Benayas et al., 2004; Akbaș et al., 2009). Analysis of wide-scale variability has practical usage in managing soil fertility and sustainability for a chosen area (Singh et al., 1985; Brady and Weil, 2002; Akbaş et al., 2009; Sharma and Jassal, 2013). Geostatistics, increasingly popular in soil science, are useful to predict the spatial distribution of spatially dependent soil properties in the field with a number of samples (McBratney and

\footnotetext{
${ }^{*}$ Corresponding author.

Ordu University, Faculty of Agricultural, Department of Soil Science and Plant Nutrition, 52200 Ordu, Turkey

Tel.: +90 452 2265200

E-mail address: tayfuna@odu.edu.tr

e-ISSN: $2147-4249$ DOI: $10.18393 /$ ejss.286626
} 
Webster, 1983; Oliver, 1987; Kerry and Oliver, 2004, Așkın and Kızılkaya, 2006; Akbaș et al., 2009; Așkın, 2010). DTPA-extractable $\mathrm{Fe}, \mathrm{Cu}, \mathrm{Mn}$ and Zinc are the dominant micronutrients in soils and hence, to understand the spatial variability was expected to better understanding of the related soil chemical parameters for long-term study within district-scale (Singh et al., 1985; Gao and Tong, 2007; Akbaş et al., 2009).

Our aim with this present study was to assess the spatial variability of soil DTPA-extractable micronutrients in district-scale using by geostatistical techniques.

\section{Material and Methods}

\section{Study site}

The study area is located in Ordu province, Altınordu district, Eastern Black sea Region, Turkey in 2015 (Figure 1).

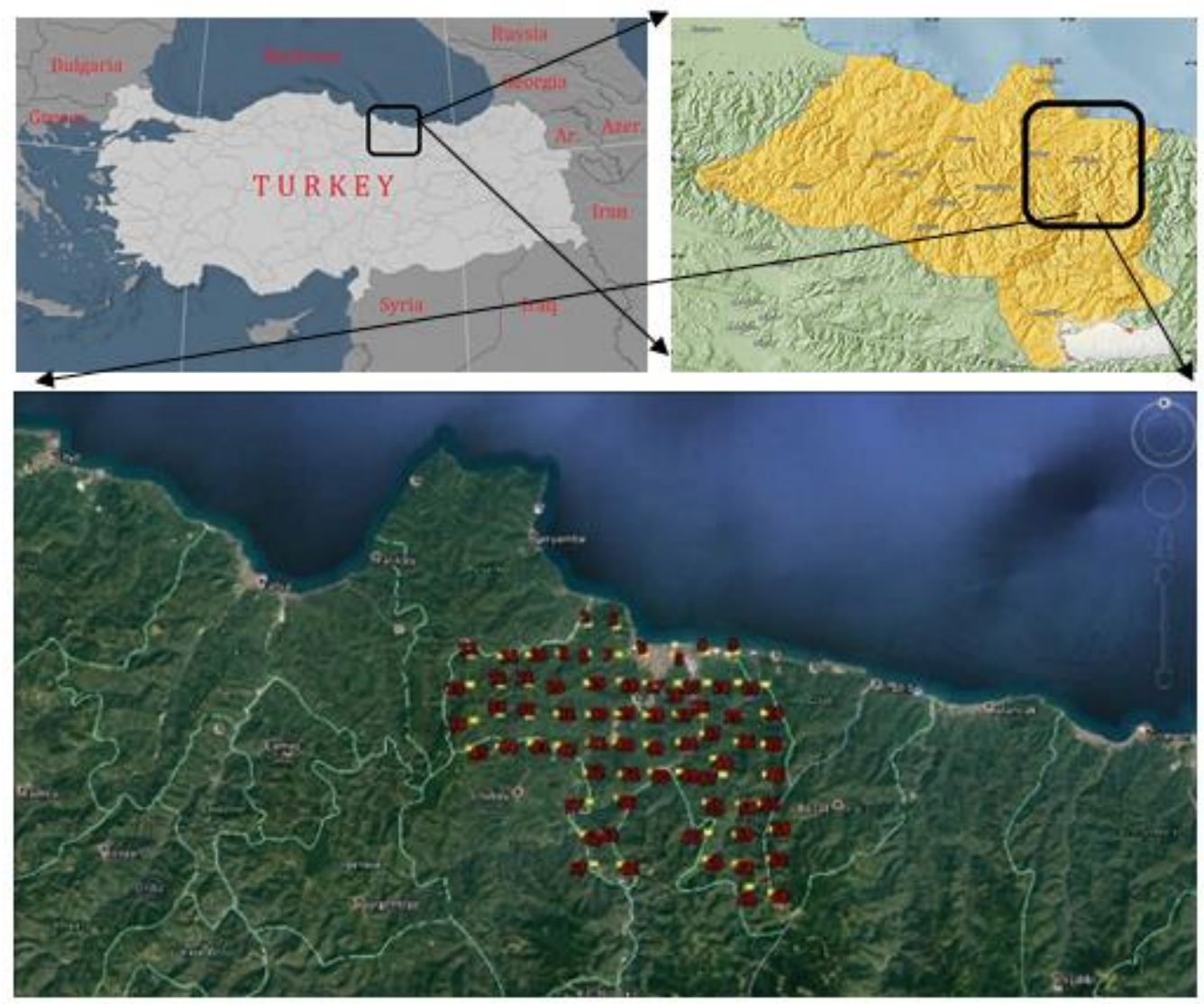

Figure 1. Location map of the study area showing the sampling design (The coordinates are in meters in UTM datum).

This area is characterized hardly sloping with a well-drained and moderate to clayey textured soil. Ordu is a center of hazelnut growing area of Turkey located near the Black sea, has typical Black sea climate with warm summers and cool winters. The highest and the lowest the temperature was from -7.2 to $37.3^{\circ} \mathrm{C}$. The annual mean temperature was $14.3^{\circ} \mathrm{C}$ and the annual mean precipitation was $1035.1 \mathrm{~mm}$ based on a 65 years period. The study site was marked with regular rectangle grids ( $2500 \times 2500 \mathrm{~m}$ each) and including 66 sampling points (Figure 1).

\section{Soil analyses}

Soil samples were air-dried and ground to pass from $2 \mathrm{~mm}$ sieve for chemical analysis. Selected soil physicochemical properties were determined by the following methods: organic carbon content by the modified Walkley-Black method (Nelson and Sommers, 1982), particle size distribution by the hydrometer method (Gee and Bauder, 1979), soil pH and electrical conductivity (EC) in 1:1 (w/v) soil-water ratio using pH-meter and EC-meter (Peech, 1965). $\mathrm{Fe}, \mathrm{Cu}, \mathrm{Mn}$ and $\mathrm{Zn}$ in soil samples were extracted with a DTPA solution $(0.005 \mathrm{M}$ DTPA $+0.01 \mathrm{M} \mathrm{CaCl} 2+0.1 \mathrm{M}$ triethanolamine, pH 7.3 as outlined by Lindsay and Norvell. The concentration of micronutrients in the extract was determined by atomic absorption spectrophotometer (Lindsay and Norvell, 1978). 


\section{Statistical analysis}

Descriptive statistics, ie, mean, standard deviation, median, minimum, maximum and data normality, were calculated using SPSS 15.0 software. Isotropic semivariances on data were calculated using $\mathrm{GS}^{+} 10.0$ geostatistical software $\left(\mathrm{GS}^{+}, 2014\right)$. Semivariance $\gamma(\mathrm{h})$ is defined in the following equation:

$$
\gamma(\mathrm{h})=\frac{1}{2 \mathrm{~N}(\mathrm{~h})} \Sigma\left[\mathrm{Z}\left(\mathrm{x}_{\mathrm{i}}\right)-\mathrm{Z}\left(\mathrm{x}_{\mathrm{i}}+\mathrm{h}\right)\right]^{2}
$$

where, $N(h)=$ the number of sample pairs at each distance interval

$\mathrm{Z}\left(\mathrm{X}_{\mathrm{i}},\right)$ and $\mathrm{Z}\left(\mathrm{X}_{\mathrm{i}}+\mathrm{h}\right)=$ the values of variable at any two places separated by distance $\mathrm{h}$.

The semivariogram is the plot of the semivariance against the distance. Its shape indicates whether the variable is spatially dependent. Experimental semivariograms were fitted by theoretical models that have well-known parameters nugget $\left(\mathrm{C}_{0}\right)$, sill $\left(\mathrm{C}_{0}+\mathrm{C}\right)$ and range $(\mathrm{A})$ of spatial dependence (Cambardella et al., 1994).

$\mathrm{GS}^{+}$has several models that can be fitted to estimate semivariograms, but in this study, we used the isotropic spherical (2) and Gaussian models (3):

$$
\begin{gathered}
\gamma(\mathrm{h})=\mathrm{Co}+\mathrm{C}\left[1,5\left(\frac{\mathrm{h}}{\mathrm{A}}\right)-0,5\left(\frac{\mathrm{h}}{\mathrm{A}}\right)^{3}\right] \\
\gamma(\mathrm{h})=\mathrm{Co}+\mathrm{C}\left[1-\exp \left(\frac{-\mathrm{h}^{2}}{\mathrm{~A}^{2}}\right)\right]
\end{gathered}
$$

Where Co is the nugget variance

$\mathrm{C}$ is the structural variance

$\mathrm{Co}+\mathrm{C}$ is the sill variance

$\mathrm{A}$ is the range of spatial correlation

In this study, point kriging was used before constructing of contour maps to provide enough estimated data. The contour maps of DTPA-extractable $\mathrm{Fe}, \mathrm{Cu}, \mathrm{Mn}$ and $\mathrm{Zn}$ contents were constructed using ArcGis software.

\section{Results and Discussion}

\section{Soil properties and DTPA-extractable micronutrients}

The soils had $39.2 \%$ sand, 26.0 silt and $34.9 \%$ clay fraction and soil textural class was named as clay loamy.

\begin{tabular}{|c|c|c|c|c|c|}
\hline Soil Properties & Mean & Minimum & Maximum & $\mathrm{S}_{\mathrm{d}}$ & $\mathrm{CV}$ \\
\hline Clay (C), \% & 34.9 & 11.9 & 69.3 & 12.86 & 36.9 \\
\hline Silt (Si), \% & 26.0 & 15.7 & 43.8 & 5.76 & 22.2 \\
\hline Sand (S), \% & 39.2 & 10.7 & 68.3 & 13.24 & 33.8 \\
\hline $\mathrm{pH}$ & 5.97 & 4.54 & 7.97 & 0.73 & 12.3 \\
\hline $\mathrm{EC}, \mathrm{dS} \mathrm{m}^{-1}$ & 0.09 & 0.02 & 0.37 & 0.08 & 86.3 \\
\hline $\mathrm{OMC}, \%$ & 2.75 & 0.43 & 6.50 & 1.48 & 53.8 \\
\hline \multicolumn{6}{|c|}{$\begin{array}{l}\text { DTPA-Extractable micronutrients } \\
\text { mg kg-1 }^{-1}\end{array}$} \\
\hline Ext-Fe & 47.75 & 10.1 & 189.6 & 36.48 & 76.57 \\
\hline Ext-Cu & 1.47 & 0.14 & 5.49 & 1.06 & 72.55 \\
\hline Ext-Mn & 38.8 & 1.2 & 136.9 & 31.47 & 81.21 \\
\hline Ext-Z) & 0.77 & 0.16 & 2.64 & 0.56 & 71.71 \\
\hline
\end{tabular}
Also descriptive statistics of soil properties are given in Table 1.

Table 1. Summary statistics on the some soil properties and DTPA-extractable micronutrients $(n=66)$

$\mathrm{S}_{\mathrm{d}}$, standard deviation; $\mathrm{CV}$, variation of coefficient

The soils were mostly clayey in texture, slightly acid in soil reaction, medium in organic matter content (average of 2.75\%) and very low in electrical conductivity $\left(<0.98 \mathrm{dS} \mathrm{m}^{-1}\right.$ ) (Soil Survey Staff, 1993). 


\section{Spatial variability of DTPA-extractable micronutrients}

Distances between Ext-Fe, Ext-Cu, Ext-Mn and Ext-Zn pairs and semivariance values were calculated using the GS+ package program. The spherical and Gaussian models with the smallest reduced sums of squares values and the biggest $\mathrm{R}^{2}$ values were selected for evaluating spatial variability of these micronutrients in the study area by the $\mathrm{GS}^{+}$package program (Table 2).

Table 2. Isotropic models fitted to variograms of DTPA-extractable micronutrients

\begin{tabular}{llllllll}
\hline $\begin{array}{l}\text { Micro } \\
\text { nutrients }\end{array}$ & Co & Co+C & $\begin{array}{l}\text { A } \\
\mathrm{m}\end{array}$ & $\begin{array}{l}\mathrm{NE} \\
\%\end{array}$ & $\mathrm{R}^{2}$ & Model & SD \\
\hline Ext-Fe & 0.011 & 0.444 & 3723 & 2.5 & 0.50 & Gaussian & S \\
Ext-Cu & 0.594 & 1.609 & 17424 & 36.9 & 0.94 & Gaussian & M \\
Ext-Mn & 0.001 & 1.193 & 3600 & 0.1 & 0.30 & Spherical & S \\
Ext-Zn & 0.019 & 0.386 & 692 & 4.9 & 0.29 & Gaussian & S \\
\hline
\end{tabular}

$\mathrm{NE}$, nugget effect $(\mathrm{Co} / \mathrm{Co}+\mathrm{C})$; SD, spatial dependence; $\mathrm{M}$, moderate; S, strong

The nugget effect (NE), representing the undetectable experimental error and field variation within the minimum sampling space, was quite large relative to the sill, which represents total spatial variation. The NE expressed in percentages can be regarded as a criterion for classifying the spatial dependence of soil properties. If the NE is less than $25 \%$, then the variable has strong spatial dependence; between 25 and $75 \%$, the variable has moderate spatial dependence; otherwise, the variable has weak spatial dependence (Chien et al., 1997).

The ranges for $\mathrm{Fe}, \mathrm{Cu}, \mathrm{Mn}$ and $\mathrm{Zn}$ were $3723 \mathrm{~m}, 17424 \mathrm{~m}, 3600 \mathrm{~m}$ and $692 \mathrm{~m}$, respectively. The highest NE occurred for Ext-Cu and with moderate spatial dependence. The lowest NE occurred for Ext-Mn with strong spatial dependence. Akbaş et al (2009) interpreted strong and moderate spatial variability as interactions among field-scale variability of soil DTPA-extractable micronutrients.

The Gaussian model for Ext-Fe, Ext-Cu and Ext-Zn and the spherical model for Ext-Mn showed the best fitting value for the computed semivariance values. The model parameters and the experimental variograms for Ext-Fe, Ext-Cu, Ext-Mn and Ext-Zn are illustrated in Figure 2a,b,c, and 2d, respectively.
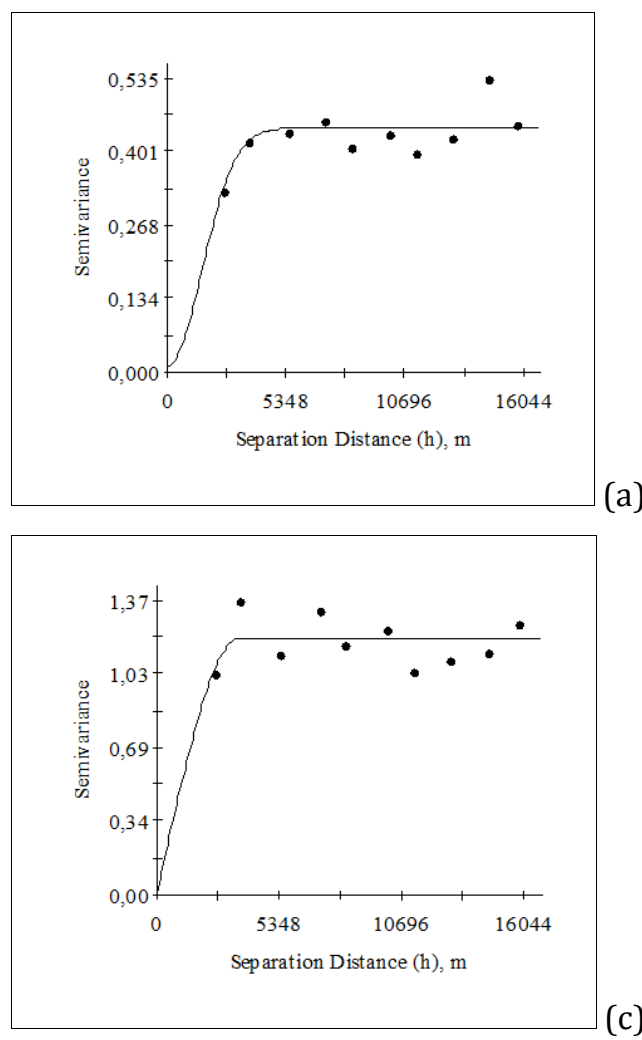
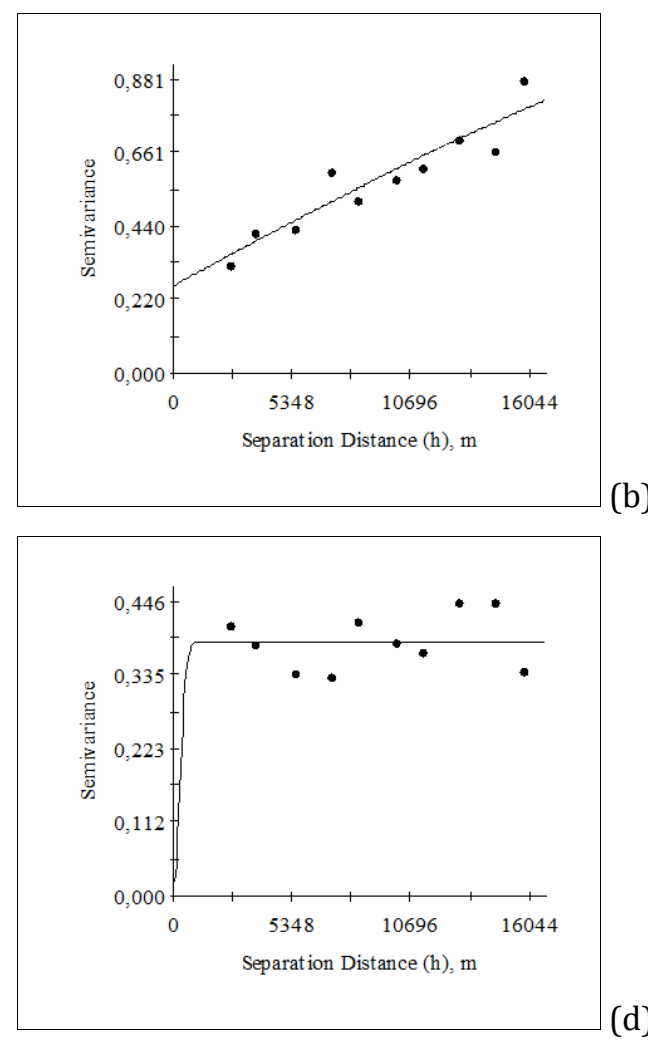

Figure 2. Isotropic semivariograms for a) Ext-Fe b) Ext-Cu c) Ext-Mn d) Ext-Zn

DTPA-extractable micronutrients were point-kriged based on the isotropic models in $250 \times 250 \mathrm{~m}$ dimensions by 8811 points using the sixteen nearest neighboring points. The descriptive statistics are presented in Table 3 for observed and point-kriged on the studied micronutrients. 


\begin{tabular}{|c|c|c|c|c|c|c|c|c|}
\hline \multirow{2}{*}{ Statistics } & \multicolumn{3}{|c|}{ Ext-Fe } & \multicolumn{2}{|l|}{ Ext-Cu } & \multicolumn{2}{|c|}{$\mathrm{xt}-\mathrm{Mn}$} & xt-Zn \\
\hline & \multicolumn{8}{|c|}{$\mathrm{mg} \mathrm{kg}^{-1}$} \\
\hline & Obs* & $\operatorname{Prd}^{* *}$ & Obs & Prd & Obs & Prd & Obs & Prd \\
\hline $\mathrm{N}$ & 66 & 8811 & 66 & 8811 & 66 & 8811 & 66 & 8811 \\
\hline Minimum & 10.1 & 10.9 & 0.14 & 0.28 & 1.2 & 1.2 & 0.16 & 0.19 \\
\hline Maximum & 189.6 & 186.2 & 5.49 & 4.00 & 136.9 & 131.1 & 2.64 & 1.66 \\
\hline Mean & 47.7 & 44.3 & 1.47 & 1.62 & 38.8 & 30.9 & 0.77 & 0.61 \\
\hline $\mathrm{Sd}$ & 36.5 & 11.7 & 1.06 & 0.51 & 31.47 & 17.99 & 0.56 & 0.13 \\
\hline \multicolumn{9}{|c|}{ Prediction errors } \\
\hline Mean & & 0.0 & & & & 0.0 & & 0.07 \\
\hline RMSs*** & & 1.0 & & & & 0.4 & & 0.93 \\
\hline
\end{tabular}

*Obs., observed; **Prd., predicted; ***RMSs, Root-Mean-Square Standardized

As seen from Table 3, the mean reduced errors were near to zero and the squared differences between the predicted and the original values, the variance of the reduced error, were the lowest for the fitted models. This means that the kriging estimates are accurate, and the spatial relationships derived from the studied part of the research site may be applicable to similar areas with this area (Trangmar et al., 1985; Öztaş, 1996; Ardahanlığlu et al., 2003; Başkan, 2004; Akbaş et al., 2009; Aşkın, 2010; Aşkın et al., 2011). The range of point-kriged Ext-Fe values (10.9-186.2 mg kg-1 with a mean of $\left.44.3 \mathrm{mg} \mathrm{kg}^{-1}\right)$ were somewhat narrower than the range of the measured Ext-Fe (10.1-189.6 mg kg-1 with a mean of $\left.47.7 \mathrm{mg} \mathrm{kg}^{-1}\right)$. The standard deviation of the kriged Ext-Fe values were lower than on the measured that this mean of selected model was true. Figure 3a shows a point-kriged map of Ext-Fe illustrated using the 8811 points.

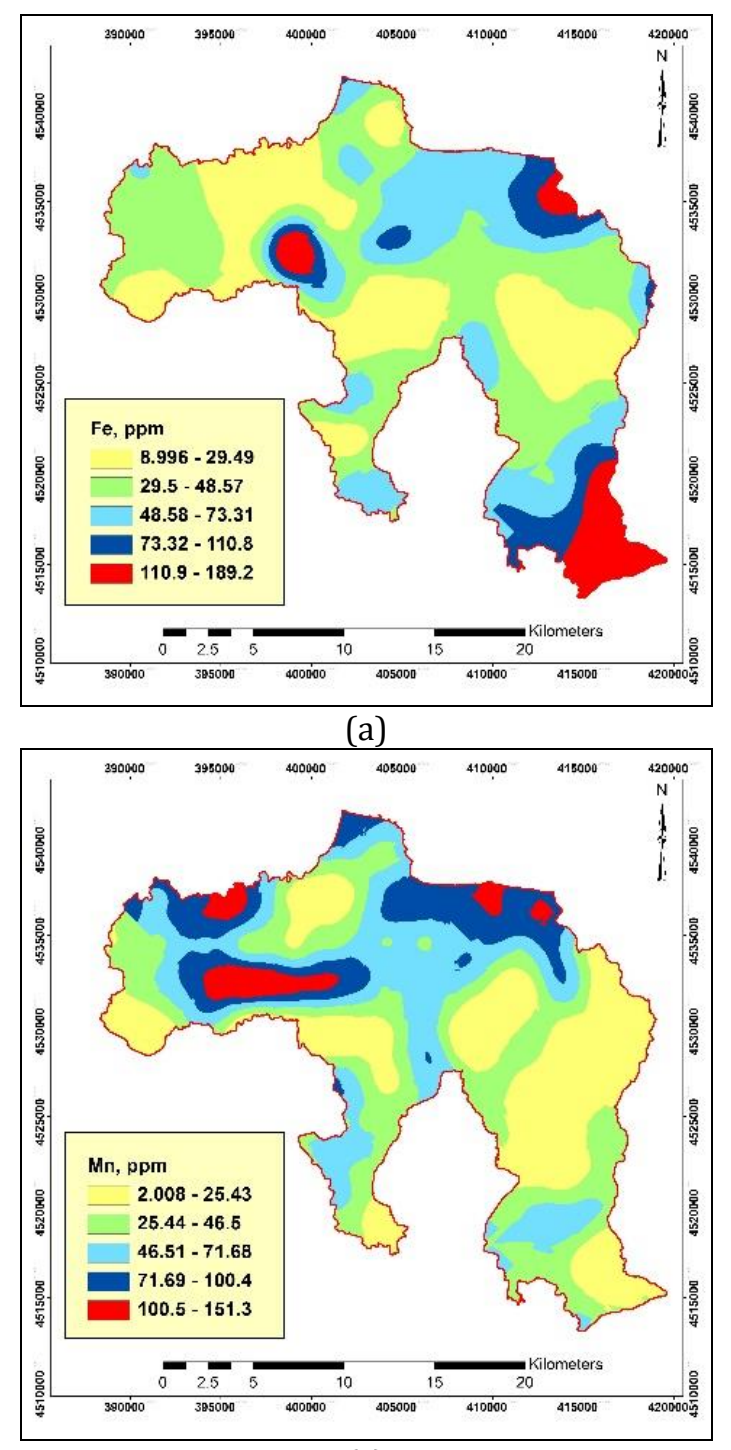

(c)

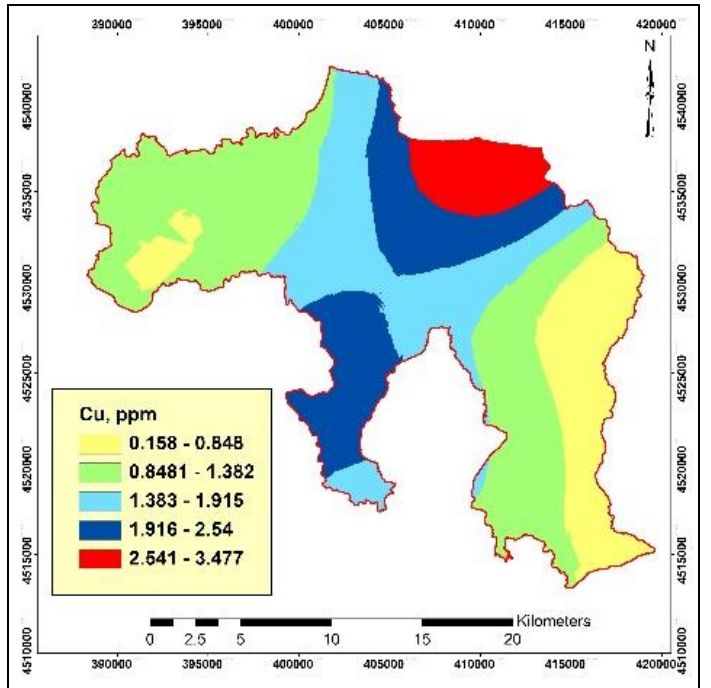

(b)

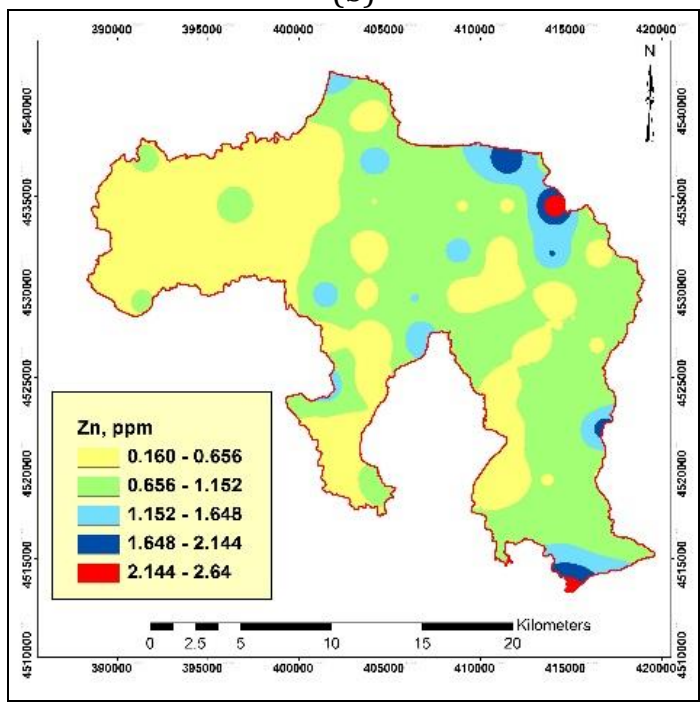

(d)

Figure 3. Point-kriged maps for a) Fe b) Cu c) Mn d) Zn 
The range of point-kriged Ext-Cu values $\left(0.28-4.00 \mathrm{mg} \mathrm{kg}^{-1}\right.$ with a mean of $\left.1.62 \mathrm{mg} \mathrm{kg}^{-1}\right)$ were somewhat narrower than the range of the measured Ext-Cu $\left(0.14-5.49 \mathrm{mg} \mathrm{kg}^{-1}\right.$ with a mean of $\left.1.47 \mathrm{mg} \mathrm{kg}^{-1}\right)$. The standard deviation of the kriged Ext-Cu values were the lower than the measured values which means of selected model is true. Figure $3 \mathrm{~b}$ shows a point-kriged map of Ext-Cu illustrated using the 8811 points.

Also Ext-Mn kriging values ranging from 1.2 to $131.1 \mathrm{mg} \mathrm{kg}^{-1}$ with a mean of $30.9 \mathrm{mg} \mathrm{kg}^{-1}$ that were somewhat narrower than the range of the measured Ext-Mn (1.2-136.9 mg kg-1 with a mean of $\left.38.8 \mathrm{mg} \mathrm{kg}^{-1}\right)$. The standard deviation of the kriged Ext-Mn values were the lower than at the measured values. Figure 3c shows a point-kriged map of Ext-Mn illustrated using the same points.

The point-kriged Ext-Zn values ranged $0.19-1.66 \mathrm{mg} \mathrm{kg}^{-1}$ with a mean of $0.61 \mathrm{mg} \mathrm{kg}^{-1}$ that were somewhat narrower than the range of the measured Ext-Zn $\left(0.16-2.64 \mathrm{mg} \mathrm{kg}^{-1}\right.$ with a mean of $\left.0.77 \mathrm{mg} \mathrm{kg}^{-1}\right)$. The standard deviation of the point kriged Ext-Zn values were the lower than on the measured values so that the selected model is true. Figure 3d shows a point-kriged map of Ext-Zn illustrated using the same points.

Huichun et al. (2015) reported that spatial variability of available soil $\mathrm{Fe}, \mathrm{Mn}, \mathrm{Cu}$, and $\mathrm{Zn}$ contents were evaluated in an ecological functional zone located at Yanqing County, Beijing, China, and their influence factors were analyzed. Their results revealed that the available soil $\mathrm{Cu}$ had a widest spatial correlation distance (e.g., $9.6 \mathrm{~km}$ ), which for available soil Fe, Mn, and Zn were only 1.29, 2.58, and $0.99 \mathrm{~km}$, respectively.

\section{Conclusion}

Assessing of the spatial variability of soil DTPA-extractable micronutrients and its affect factors are huge importance for applications such as fertilization, sustainable soil use and environmental protection especially for agricultural ecosystems. The range of spatial dependence ranged from 692 to $17424 \mathrm{~m}$, indicating that the grid scale was adequate for assessing of the spatial variability of the DTPA-extractable micronutrients. In this area or a similar land, in soil productivity and fertility research studies to be done about sampling interval can be chosen. Although the Gaussian isotropic model was the best semivariogram model for Ext-Fe, Ext-Cu and Ext-Zn and the spherical model was the best for Ext-Mn. The information obtained from geostatistical techniques can be used to gain a better understanding of the spatial distribution of DTPA-extractable micronutrients status in the district topsoil. This approach enabled mapping of soil plant nutrients in the district-scale. Our results suggested that the use of kriging should decrease the required sampling density in the district-scale. Spatial analysis on soil micronutrients could be useful for assessing soil fertility status and soil quality, as well as developing appropriate sampling strategies. Also our results should help goals on site specific management applications in study area or similar lands.

\section{Acknowledgements}

The authors extent hearthfelt gratitude for the financial support from Ordu University Scientific Researches Project Coordination Department (ODU-BAP) and the scientific research grand (AR-1221).

\section{References}

Akbaş, F., Günal, H., Gökmen, F., Gezgin, S., Erşahin, S., 2009. Spatial variation of micronutrients in topsoil and subsoil of Vertic Haplustepts. Agrochimica 53(2): 101-116.

Ardahanloğlu, I., Öztas, T., Evren, S., Yılmaz, T., Yıldırım, Z.N., 2003. Spatial variability of exchangeable sodium, electrical conductivity, soil $\mathrm{pH}$ and boron content in salt- and sodium-affected areas of the Iğdır plain (Turkey). Journal of Arid Environment 54(3): 495-503.

Așkın, T., Kızılkaya, R., 2006. Assessing spatial variability of soil enzyme activities in pasture topsoils using geostatistics. European Journal of Soil Biology 42(4): 230-237.

Aşkın, T., 2010. Evaluation of some soil properties as related to landscape position using geostatistical techniques, International Scientific and Practical Conference on Scientific Support - To Innovative Development of the AgroIndustrial Complex), 18-19 November, Perm State Agricultural Academy, Perm, Russia, p. 34-40.

Aşkın, T., Sinitsa, Y.N., Kızılkaya, R., 2011. The spatial variability of arylsulphatase activity: A study from agricultural ecosystems, International Conference on "Resource Potential of Soils - The Basis of the Food and Ecological Safety of Russia", 1-4 March, Saint Petersburg State University, Saint Petersburg, Russia, p. 324-327

Başkan, O., 2004. Gölbaşı yöresi topraklarının mühendislik, fiziksel özellik ilişkilerinde jeoistatistik uygulaması. Ankara Üniversitesi Fen Bilimleri Enstitüsü Toprak Anabilim Dalı, Doktora Tezi, Ankara. [in Turkish]

Benayas, J.M.R., Sachez-colomer, M.G., Escudero, A., 2004. Landscape- and field-scale control of spatial variation of soil properties in Mediterranean montane meadows. Biogeochemistry 69(2): 207-225.

Brady, A.C., Veil, R.R., 2002. The nature and properties of soils. 13th edition, Prentice Hall. New Jersey, USA. 
Cambardella, C.A., Moorman, A.T., Novak, J.M., Parkin, T.B., Karlen, D.R., Turco, R.F., Konopka, A.E., 1994. Field-scale variability of soil properties in central Iowa soils. Soil Science Society America Journal 58(5): 1501-1511.

Chien, Y.J., Lee, D.Y, Guo, H.Y., Houng, K.H., 1997. Geostatistical analysis of soil properties of mid-west Taiwan soils. Soil Science 162(4): 291-298.

Epstein, E., 1972. Mineral Nutrition of Plants: Principles and Perspectives, John Wiley \& Sons, New York, USA.

Gao, Y.M., Tong, Y.A., 2007. Spatial variability and distribution of five soil microelements content in farmland of Guanzhong Plain. Journal of Northwest A \& F University (Natural Science Edition) 53: 121-127.

Gee, G.W., Bauder, J.W., 1979. Particle size analysis by hydrometer: a simplified method for routine textural analysis and a sensitivity test of measured parameters. Soil Science Society America Journal 43(5): 1004-1007.

Glass, D.M. 1989. Plant Nutrition: An Introduction to Current Concepts. Jones and Bartlett Publishers, Boston, MA, USA.

GS+, 2014. Gamma Design Software LLC.. P.O. Box 201, Plainwell, Michigan, USA.

Huichun Y., Chongyang S., Yuanfang H., Wenjiang H., Shiwen Z. ,Xiaohong J., 2015. Spatial variability of available soil microelements in an ecological functional zone of Beijing. Environmental Monitoring and Assessment 187:13.

Kerry, R., Oliver, M.A., 2004. Average variograms to guide soil sampling. International Journal of Applied Earth Observation and Geoinformation 5(4): 307-325.

Lindsay, W.L., Norvell, W.A., 1978. Development of a DTPA soil test for zinc, iron, mangasese, and copper. Soil Science Society America Journal 42(3): 421-428.

McBratney, A.B., Webster, R., 1983. Optimal interpolation and isarithmic mapping of soil properties: V. Co regionalization and multiple sampling strategy. European Journal of Soil Science 34(1): 137-162.

Nelson, D.W., Sommers, L.E. 1982. Total carbon, organic carbon and organic matter. In: Methods of soil analysis. Part 2. Chemical and microbiological properties. Page, A.L. Miller, R. H., Keeney, D.R. (eds.). American Society of Agronomy, Madison, WI, USA. pp. 539-577.

Oliver, M.A., 1987. Geostatistics and its application to soil science. Soil Use and Management 3(1): 8-19.

Öztas, T., 1996. Identifying spatial variability of soil depth lost to erosion in a rolling landscape using Kriging analysis. Symposium on Agriculture-Environment Relations, p. 327-335, Mersin, Turkey.

Peech, M., 1965. Hydrogen-ion activity. In: Methods of soil analysis. Part 2. Chemical and microbiological properties. Black, C.A. (ed.). American Society of Agronomy, Madison, WI, USA. pp. 914-925,

Römheld, V., Marschner. H., 1991. Function of micronutrients in plants. In: Micronutrients in Agriculture. Morvedt, J.J., (ed.). 2nd ed., Soil Science Society of America Book Series Number 4, Madison, WI, USA. pp. 297-328.

Sharma, B.D., Jassal, H.S., 2013. Study of a toposequence for variability in micronutrients from the moist subhumid Siwalik agro-ecological subregion of Punjab. Archives of Agronomy and Soil Science 59(4): 573-591.

Singh, J.P., Karamanos, R.E., Kachannoski, R.G., 1985. Spatial variability of extractable micronutrients in a cultivated and native prairie soil. Canadian Journal Soil of Science 65(1): 149-156.

Singh, M.V., 2008. Micronutrient fertility mapping for Indian soil, Technical Bulletin. AICRP Micronutrients, IISS, Bhopal. 7: $1-60$.

Soil Survey Staff, 1993. Soil Survey Manual. USDA Handbook No. 18, United States Government Printing Office, Washington, DC, USA.

Thakur, R., Kauraw, D.L., Singh, M., 2011. Profile distribution of micronutrient cations in a Vertisol as influenced by long-term application of manure and fertilizers. Journal of the Indian Society of Soil Science 59(3): 239-244.

Trangmar, B.B., Yost, R.S., Uehara, G., 1985. Application of geostatistics to spatial studies of soil properties. Advances in Agronomy 38: 45-93. 